\title{
Cost-Effectiveness Analysis of Somatostatin Analogues in the Treatment of Acromegaly in Brazil
}

\section{original article}

\author{
JoICE VALENTIM \\ VANessa Passos \\ FABIO MATAVELI \\ Alessandra Calabró
}

Departamento de Medicina

Preventiva, Faculdade de

Medicina, Universidade de São

Paulo (USP) (JV), São Paulo, SP,

Brasil; Novartis Pharmaceuticals

(VP), Estados Unidos; Clínica

Médica, Medicina, Universidade

Federal de São Paulo (Unifesp)

(FM); Novartis Biociências S.A.

(AC); São Paulo, SP, Brasil.

This study aims to compare economic and patient impacts of the treatment of acromegaly with two different somatostatin analogues (octreotide LAR and lanreotide SR) in Brazil. A cost-effectiveness analysis was carried out under the Brazilian Public Health Care System (SUS) perspective. A decision analytical model was developed based on the Brazilian Public Health Care System Clinical Guideline for Acromegaly. A hypothetical cohort of 276 patients was followed for two years. Data were extracted from literature and administrative databases. Based on the analytical model, treatment with octreotide LAR would avoid 12 and 17 cases of GH and IGF-I elevated serum levels, respectively. Octreotide LAR was a cost-saving strategy, with net savings of $R \$ 10,448,324$ (US $\$ 4,465,096)$ to SUS. Annual net savings per patient were R\$ 18,928 (US\$8,089). Treatment of acromegaly with octreotide LAR is a dominant strategy when compared to the treatment with lanreotide SR in Brazil. Sensitivity analysis did not alter the cost-saving status. (Arq Bras Endocrinol Metab 2008; 52/9:1452-1460)

Keywords: Cost effectiveness; Acromegaly; Somatostatin analogues; Octreotide; Lanreotide

\section{RESUMO}

Análise de Custo-Efetividade de Análogos da Somatostatina no Tratamento de Acromegalia no Brasil.

O objetivo deste estudo é comparar o impacto econômico e o impacto nos pacientes com acromegalia do tratamento com dois diferentes análogos de somatostatina (octreotida LAR e lanreotide SR) no Brasil. Um estudo de custoefetividade foi realizado a partir da perspectiva do Sistema Único de Saúde (SUS). Foi desenvolvido um modelo analítico de decisão baseado no Protocolo Clínico e Diretrizes Terapêuticas de Acromegalia do SUS. Uma coorte hipotética de 276 pacientes foi seguida por dois anos. Dados foram obtidos da literatura e bases de dados oficiais do SUS. Baseado no modelo analítico, o tratamento com octreotida LAR evitaria 12 e 17 casos com níveis elevados de GH e IGF-I, respectivamente. Octreotida LAR foi uma estratégia econômica, gerando economia de $\mathrm{R} \$ 10.448 .324$ (US\$4.465.096) para o SUS. A economia anual por paciente foi de $\mathrm{R} \$ 18.928$ (US\$8.089). O tratamento de acromegalia com octreotida LAR é estratégia dominante quando comparado com o tratamento com lanreotida SR no Brasil. A análise de sensibilidade não alterou seu status de econômica. (Arq Bras Endocrinol Metab 2008; 52/9:1452-1460)

Descritores: Custo-efetividade; Acromegalia; Análogo de somatostatina; Octreotida; Lanreotida.

\section{INTRODUCTION}

Received in $1 / 4 / 2008$ Acepted in 4/8/2008 cromegaly is a rare chronic endocrine disease caused by growth hormone $(\mathrm{GH})$ hypersecretion. A pituitary somatotroph adenoma is the sour- 
ce of this hypersecretion in more than $95 \%$ of the cases. GH stimulates hepatic production of insulin-like growth factor-I (IGF-I). Some somatic effects are directly produced by $\mathrm{GH}$, while others are mediated by IGF-I (1). The annual incidence of this disease is 3-4 cases per million with a prevalence of 40-70 cases per million (2-3). The disease presents the same frequency for men and women and its mean age of onset is estimated to be $30-50$ years (2-4). Due to its slowly progressive nature, formal diagnosis often occurs 10 years after the first symptoms and signs appear (4). Complications associated to acromegaly are cardiovascular, respiratory and neoplasic diseases, that contribute to the increased mortality rate related to this disease, which is 2-4 times higher than that of an age and sex matched population (4-5). Adequate treatment, as well as early diagnosis, may revert the increased mortality risk in acromegalic patients. There are no epidemiological studies of the Brazilian population on acromegalic patients (4).

Diagnosis includes clinical assessment; laboratory tests (measures of GH, IGF-I levels and GH evaluation during the oral glucose tolerance test); MRI or CT scan; and histopathologic assessment when patient undergoes surgery (4).

Management of acromegaly is complex and presents many treatment options. Surgery is the primary treatment option. The rate of success in transsphenoidal surgery (TS) depends on the experience and ability of the neurosurgeon, on the tumor size and extension and on the pre-surgery GH level. Over 30\% of tumors are microadenomas and 70\% macroadenomas (6). Remission rate post-surgery is over $70-80 \%$ in patients with microadenomas and less than $50 \%$ in patients harboring macroadenomas, in the hands of experienced surgeons (7-8). Surgical expertise is defined as training experience of more than 100 pituitary surgeries cases and annual surgical activity of more than $25 \mathrm{ca}$ ses/year (9-11).

Medical treatment options are somatostatin analogues, octreotide [Octreotide has two presentations: subcutaneous (sc), daily injection, and depot (LongActing Release - LAR), whose administration occurs every 28 days] LAR (Sandostatin ${ }^{\circledR}$ LAR, Novartis) and lanreotide [Lanreotide has two formulations: SR (Slow Release), a depot presentation administered every 14 days (interval which can be reduced to 7 days) and Autogel, a deep subcutaneous injection, administered every 28 days] SR (Somatuline ${ }^{\circledR}$ LA, Ipsen); dopamine agonists, bromocriptine (Parlodel $®$, Novartis) and cabergoline (Dostinex ${ }^{\circledR}$, Pfizer). A novel approach is the receptor antagonist, pegvisomant (Somavert ${ }^{\circledR}$, Pfizer). Radiotherapy is a third-line treatment whose modalities are conventional radiotherapy, available throughout the Brazilian Healthcare System, and radiosurgery, restricted to some reference centers (4).

In 2002, the Brazilian Public Health Care System (SUS) released a Clinical Guideline for Acromegaly. The drug class of somatostatin analogues became available in the Brazilian Public Healthcare System for the treatment of patients with acromegaly (12). Regarding dopamine agonists, cabergoline also became available in 2002 whereas bromocriptine was already on SUS drug list. Octreotide subcutaneous and LAR, bromocriptine and cabergoline are on the list of "Exceptional Drugs", one of the programs of free-of-charge drug dispensation provided by SUS. Lanreotide SR was also available until 2006.

Considering the medical treatment options available in SUS, our objective is to perform a cost-effectiveness analysis (CEA) of acromegaly treatment with somatostatin analogues under the Public Health Care System perspective (SUS), in order to compare different strategies of treatment, based on the Brazilian Guideline (12). Economic evaluation studies of acromegaly are rare in the literature $(13,14)$, and there is no study applied to Brazil.

\section{METHODS}

\section{Model and Clinical Parameters}

The treatment algorithm of Acromegaly outlined by the Brazilian Public Health Care System Clinical Guideline for Acromegaly (12) indicates the use of somatostatin analogues, for patients with macroadenomas or microadenomas who have not presented controlled GH levels after transsphenoidal surgery and patients with invasive macroadenomas, not surgically removable. Based on this algorithm, treatment with somatostatin analogues should last initially three months in case of depot presentation. Evaluating the patient after three months would determine the physician conduct: continue the somatostatin analogue when GH level is controlled or increase its dose in case of a high GH level. If $\mathrm{GH}$ level is not controlled after dose increase of either octreotide LAR or lanreotide SR, the medical treatment should be substituted by a dopamine agonist. If 
still not responding (high $\mathrm{GH}$ level) the physician should consider association of somatostatin analogue and dopamine agonist or reconsider surgery and/or radiotherapy.

Based on the Brazilian Guideline for the treatment of Acromegaly (12) above described, a decision analytical model was developed in Microsoft Excel. The decision tree is presented in Figure 1.

The initial strategies compare the treatments with two somatostatin analogues: 1) Treatment with octreotide LAR; 2) Treatment with lanreotide SR (Lanreotide Autogel was not included as a strategy in this model. The product and its price is not available in SUS drug list. Furthermore there is a lack of robust scientific data on the literature regarding tumor reduction and its comparison to other drugs).

Time horizon was established in two years, according to what had been done in the literature (13). Two years is sufficient to assess if the patient will respond to somatostatin analogue or not.

The model followed the sequence of possible treatment options set by the Guideline (12), applying an initial three-month period in the new treatment, when it has to be changed (in the case of high GH levels). According to that period and to the treatment sequences, patients going to radiotherapy would stay on this treatment for a year. Control of hormone levels usually begins after a period of six months until two years after starting radiotherapy (15). In a study in the United Kingdom, it was shown that hormone levels were controlled after two years (16). The late response to radiotherapy implies, in this model, that patients in the radiotherapy branch are not assessed to GH level control. Radiotherapy technique in the model is the linear accelerator. The treatment would happen in 25 fractions in three different fields.

The outcomes considered in the analysis were biochemical efficacy endpoints, cases of elevated GH and IGF-I avoided, and life years saved (LYS). Although normalization of $\mathrm{GH}$ level is the only criteria presented in the Brazilian Guideline (12), control of IGF-I level was also considered in the analysis to reflect the clinical practice (17). As there is no consensus in the literature about the use of IGF-I as a predictor of long-term outcome (17), mortality reduction was related only to normalization of GH level in the model.

The Brazilian Guideline establishes as controlled GH levels values $<2 \mathrm{ng} / \mathrm{mL}$ (12). In the present study, based on the last consensus (9) values below $2.5 \mathrm{ng} / \mathrm{mL}$ were considered as controlled GH levels. Furthermore it is also in accordance to the values that were used in a metaanalysis of long-acting somatostatin analogues therapy in acromegaly, in which efficacy endpoint was defined as $\mathrm{GH}$ level $<2,5 \mathrm{ng} / \mathrm{mL}$ in most of the studies evaluated (18). In this meta-analysis (18) octreotide LAR and lanreotide SR are the second therapy after transsphenoidal surgery and/or radiotherapy and octreotide sc. The percentage of patients with no previous treatment was too low and as a consequence they were assessed along with the patients in the secondary treatment.

In the base case scenario, according to Freda and cols. (18), for GH control octreotide LAR had an efficacy of $57 \%$ and lanreotide SR efficacy of $48 \%$. For IGFI control, octreotide LAR had an efficacy of $67 \%$ and

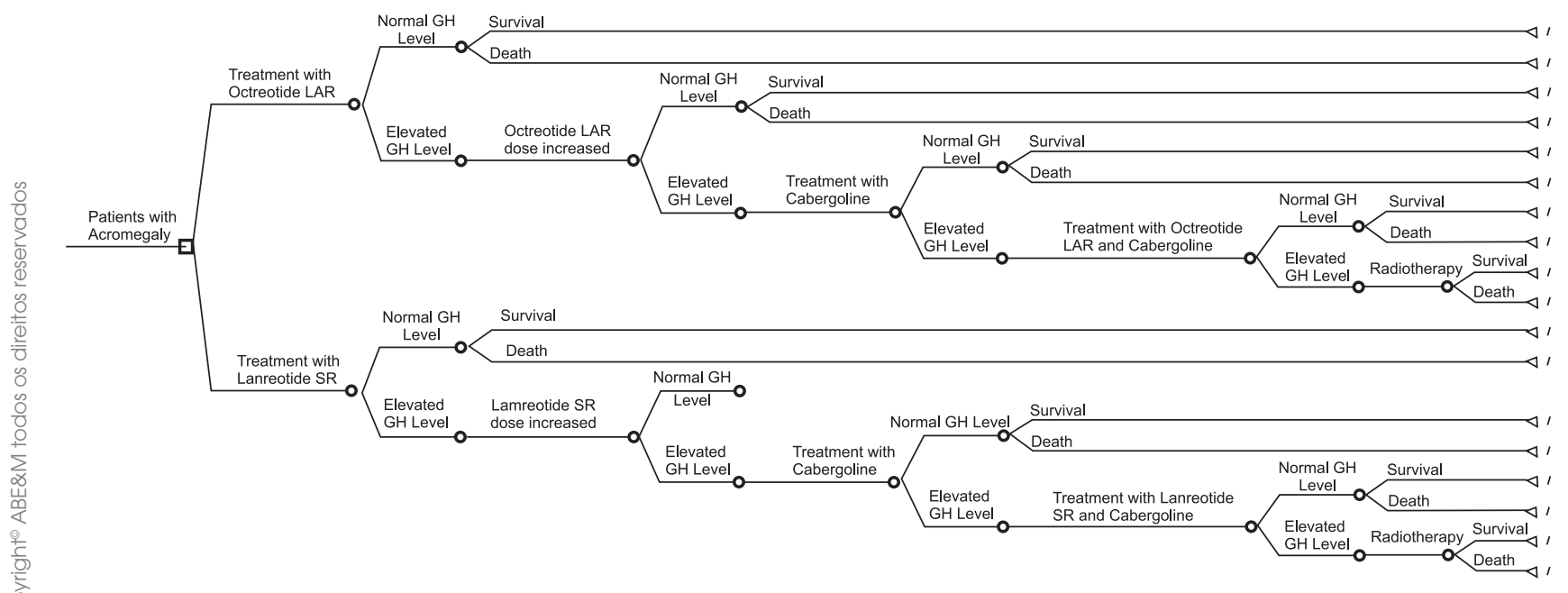

Figure 1. Decision tree - acromegaly treatment in Brazil. 
lanreotide SR 47\%. Cabergoline was the dopamine agonist considered in the model, with efficacy of $37 \%$ (13). Regarding the association of somatostatin analogues and cabergoline, the efficacy data available combines data from both octreotide LAR and lanreotide SR. Because of that the same efficacies (21\% for GH and $42 \%$ for IGF-I normalizations) were used for the association of cabergoline with any somatostatin analogue (19).

Regarding drug dosage, initial dose of $20 \mathrm{mg}$ of octreotide LAR every 28 days was considered in the $1^{\text {st }}$ strategy and $30 \mathrm{mg}$ of lanreotide SR every 14 days in the $2^{\text {nd }}$ strategy. The dose increase considered $30 \mathrm{mg}$ of octreotide LAR every 28 days and $60 \mathrm{mg}$ of lanreotide SR every 14 days (equivalent to $30 \mathrm{mg}$ of lanreotide SR every 7 days). Cabergoline would be administered $1 \mathrm{mg} /$ week alone or in association with one somatostatin analogue. In case of association, octreotide LAR and lanreotide SR doses are the same assumed for dose increase.

Tumor shrinkage was not included in the model. Tumor shrinkage occurs in $88,5 \%$ and $50,7 \%$ of the patients when treated primarily with octreotide LAR and lanreotide SR, respectively (18). When somatostatin analogues are used as secondary treatment $47 \%$ and $21 \%$ of tumor shrinkage is expected with octreotide LAR and lanreotide SR, respectively (18).

Based on the Brazilian Guideline (12), it was assumed that if GH control is not achieved after surgery, drug therapy would be the next treatment option. Data for GH control failure post surgery came from the literature $(7,8,20)$, with microadenomas not presenting GH control after the intervention in $20-30 \%$ of the cases and macroadenomas in $50 \%$ of the cases. Conside- ring that macroadenomas represents around $70 \%$ of the cases (6), it was estimated in the model that $50 \%$ of the acromegalic patients are treated with medical therapy in case of GH control failure post surgery. This proportion was applied to the incidence of 3 cases per million per year, lower estimate, given the difficult diagnosis of this disease. Considering this incidence, the proportion of medical therapy usage and a population of 184.184. 074 in Brazil in 2005 (DATASUS), the model followed a hypothetical cohort of 276 patients diagnosed with acromegaly in 2005 .

Mortality rate was calculated for the specific age group of $40-49$ years, $0.43 \%$ per year in 2005 (21), given that mean average of diagnosis may start at 30 years of age with a 10-year delay. Mortality rate for acromegaly was calculated as the double of the general mortality rate for the matched age group $(0.86 \%$ per year). When GH level is under control, mortality rate decreases back to $0.43 \%$ per year in the model.

\section{Costs}

Costs were estimated for the Brazilian Public Health Care System (SUS). Unit costs were consulted in the Public Health Care databases and resource uses estimated from the Brazilian Guideline (12) for Acromegaly and literature (13). Costs were estimated to 2005, when lanreotide SR was still available in the Public Health Care System Program of Medicine Dispensation.

Table 1 shows somatostatin analogue costs per presentation in the Public Health Care System (Negotiation between the producer and the government results

Table 1. Cost per somatostatin analogue in the Public Health Care System (SUS) for acromegaly treatment , Brazil, 2005 reais (R\$).

\begin{tabular}{|c|c|c|c|c|c|}
\hline \multicolumn{6}{|c|}{ Somatostatin analogue: octreotide LAR } \\
\hline Dose (mg) & Interval (days) & Total dose per year $(\mathrm{mg})$ & Cost per presentation & Cost per mg & Total Annual Cost \\
\hline 10 & 28 & 130.36 & RS 1,369.62 & RS 136.96 & $\mathrm{R} \$ 17,853.98$ \\
\hline 20 & 28 & 260.71 & $R \$ 2,106.97$ & R\$ 105.35 & $R \$ 27,465.86$ \\
\hline 30 & 28 & 391.07 & R\$ 2,844.37 & $\mathrm{R} \$ 94.81$ & R\$ 37,077.35 \\
\hline \multicolumn{6}{|c|}{ Somatostatin analogue: lanreotide SR } \\
\hline Dose (mg) & Interval (days) & Total dose per year (mg) & Cost per presentation & Cost per mg & Total Annual Cost \\
\hline 30 & 14 & 782.14 & R\$ 1,556.01 & $\mathrm{R} \$ 51.87$ & $R \$ 40,569.75$ \\
\hline 30 & 10 & $1,095.00$ & $R \$ 1,556.01$ & $R \$ 51.87$ & R\$ 56,797.65 \\
\hline 30 & 7 & $1,564.30$ & $\mathrm{R} \$ 1,556.01$ & $\mathrm{R} \$ 51.87$ & $\mathrm{R} \$ 81,139.50$ \\
\hline
\end{tabular}

Source: Ambulatory Information System (SIA) - DATASUS. 
in medicine prices being lower in the Public Health Care System). For the different possible dosages and intervals of each somatostatin analogue, an average annual cost per patient was calculated in order to compare economic impact of hypothetical cases, previously to the modeling. Comparing an annual treatment of $20 \mathrm{mg} / 28$ days of octreotide LAR to another of $30 \mathrm{mg} / 14$ days of lanreotide SR, octreotide LAR annual cost represents less than half of lanreotide SR cost.

Costs included in the decision analytical model were direct medical costs, in ambulatory care. For sensitivity analysis, hospitalization was considered too. Component items are medicines, radiotherapy and monitoring, which includes consultations, GH and IGF-I level tests. Monitoring tests specific to the somatostatin analogues use were glucose, TSH and abdominal ultrasound. For the two years follow-up, costing estimated 8 consultations, 8 IGF- 1 level tests, $8 \mathrm{GH}$ level tests and 4 ultra-sounds. Glucose and TSH tests would occur every three months after start use of somatostatin analogues. It was assumed that there was no increase of the use of resources in case of no response to any treatment, as acromegaly is a chronic disease which requires constant medical supervision. For radiotherapy, conventional (linear accelerator) modality for 3 fields and 25 fractions were used for costing. Planning radiotherapy cost was added, summing up a radiotherapy cost of $\mathrm{R} \$ 1,353.03$ per patient. Death cases were assumed to use, on average, half the resources of survival cases (as secondary data were used to model the disease and its treatment, it is not known in which point of the time along the 2-year time horizon deaths occur. As an assumption, the follow-up of cases resulting in death would correspond, on average, to 1 year).

Table 2 summarizes model parameters, maximum and minimum limits adopted in sensitivity analysis.

Once acromegaly is a chronic disease, treatment costs are continuous. In the model, costs and outcomes refer to the 2-year period. Deaths and life years saved (LYS) were computed only to this period.

As model time horizon is short, costs and outcomes were not discounted.

\section{RESULTS}

\section{Base case}

Results are presented in Tables 3 and 4.
Costs are detailed for each strategy in Table 3. Total costs are split by management modality (somatostatin analogue; somatostatin analogue dose increase; substitution for cabergoline; association of somatostatin analogue and cabergoline; radiotherapy). For each branch of the decision tree there is the respective costs, either for treatment(s) or monitoring and the number of patients on that branch. Average annual cost per patient was R\$ 27,359 for octreotide LAR and R\$ 46,287 for lanreotide SR.

The incremental cost was negative, - $\mathrm{R} \$ 10,448,324$ (Table 4). There were net savings for octreotide LAR when it was the somatostatin analogue used in the treatment of acromegaly. Considering the official exchange rate of R $\$ 2,34 /$ US\$1 in 2005 (Banco Central do Brasil), the net savings would be US\$ 4,465,096. Net savings per patient per year were R\$ 18,928 (US\$8,089).

In comparison to lanreotide SR, 12 cases of GH and 17 cases of IGF-I elevated would be avoided when octreotide LAR was the chosen therapy, resulting in 0.1 death avoided and 0.2 life year saved (LYS) (Table 4). With lanreotide SR there would be 2.7 deaths estimated from the model against 2.6 deaths with octreotide LAR. The avoidance of 0.1 death in 2 years would yield an increment of over $8 \%$ in life years saved for octreotide LAR. The life year saved increment calculation was done as described below:

$$
\begin{aligned}
& \text { Death(s) avoided * } \\
& \text { Life year saved }=\frac{\text { Model time horizon }(2 \text { years })}{\text { Number of }} \\
& \text { increment }=\frac{\text { Number of deaths with }}{} \\
& \text { octreotide LAR strategy }
\end{aligned}
$$

As the treatment with octreotide LAR is more efficacious according to the meta-analysis available (18) and less costly in Brazil, this strategy is dominant when compared to the lanreotide SR strategy. The Incremental Cost-Effectiveness Ratio (ICER) is cost-saving.

\section{Sensitivity analysis}

The following variables were included in sensitivity analysis: drug efficacy, drug dose, somatostatin analogue prices and inclusion of hospitalization by acromegaly (Table 5).

Somatostatin analogue prices varied in sensitivity analysis according to CAP (Coeficiente de Adequação 
Table 2. Model Parameters.

\begin{tabular}{|c|c|c|c|c|}
\hline \multirow[t]{2}{*}{ Parameter } & \multirow[t]{2}{*}{ Base case } & \multicolumn{2}{|c|}{ Sensitivity analysis } & \multirow[t]{2}{*}{ Source } \\
\hline & & Minimum & Maximum & \\
\hline \multicolumn{5}{|l|}{ Dose } \\
\hline \multicolumn{5}{|l|}{ Drug } \\
\hline octreotide LAR & 20 mg / 28 days & $20 \mathrm{mg} / 28$ days & $30 \mathrm{mg} / 28$ days & $\begin{array}{l}\text { Portaria 471, 24/07/2002; Cook and } \\
\text { cols. (2004); Freda and cols.(2005) }\end{array}$ \\
\hline lanreotide SR & 30 mg / 14 days & $30 \mathrm{mg} / 14$ days & $30 \mathrm{mg} / 7$ days & $\begin{array}{l}\text { Portaria 471, 24/07/2002; Cook and } \\
\text { cols. (2004); Freda and cols.(2005) }\end{array}$ \\
\hline cabergoline & $1 \mathrm{mg} /$ week & $1 \mathrm{mg} /$ week & $3,5 \mathrm{mg} /$ week & Cozzi and cols. (2004) \\
\hline \multicolumn{5}{|l|}{ Costs ${ }^{1}$} \\
\hline \multicolumn{5}{|l|}{ Drug $^{2}$} \\
\hline octreotide LAR & R\$ 2,288.82 & $R \$ 2,288.82$ & R\$ 3,089.80 & SIA/Datasus; Portaria 471, 24/07/2002 \\
\hline lanreotide SR & R\$ 3,380.82 & $R \$ 3,380.82$ & $R \$ 6,761.63$ & SIA/Datasus; Portaria 471, 24/07/2002 \\
\hline cabergoline & $R \$ 127.20$ & R\$ 127.20 & $\mathrm{R} \$ 445.20$ & SIA/Datasus; Portaria 471, 24/07/2002 \\
\hline \multicolumn{5}{|l|}{ Radiotherapy ${ }^{3}$} \\
\hline $\begin{array}{l}\text { Linear accelerator } \\
\text { (per field) }\end{array}$ & R\$ 17.49 & - & - & SIA/Datasus \\
\hline Planning & $\mathrm{R} \$ 41.28$ & - & - & SIA/Datasus \\
\hline \multicolumn{5}{|l|}{ Monitoring ${ }^{3}$} \\
\hline $\begin{array}{l}\text { Endocrinologist } \\
\text { consultation }\end{array}$ & $R \$ 7.56$ & - & - & SIA/Datasus \\
\hline IGF-1 & $R \$ 13.38$ & - & - & SIA/Datasus \\
\hline $\mathrm{GH}$ & $\mathrm{R} \$ 11.40$ & - & - & SIA/Datasus \\
\hline Ultra-sound & R\$ 14.52 & - & - & SIA/DATASUS \\
\hline Glucose & R\$ 1.85 & - & - & SIA/DATASUS \\
\hline $\mathrm{TSH}$ & $\mathrm{R} \$ 7.23$ & - & - & SIA/DATASUS \\
\hline Hospitalization ${ }^{3}$ & - & - & R\$ 709.40 & SIH/DATASUS \\
\hline Surgery ${ }^{4}$ & - & - & - & SIH/DATASUS \\
\hline \multicolumn{5}{|l|}{ Efficacy } \\
\hline \multicolumn{5}{|l|}{ GH (IGF-I) level control } \\
\hline octreotide LAR & $57 \%(67 \%)$ & $54 \%$ & $58 \%$ & Freda and cols. (2005) \\
\hline lanreotide SR & $48 \%(47 \%)$ & $48 \%$ & $50 \%$ & Freda and cols. (2005) \\
\hline cabergoline & $37 \%$ & $28 \%$ & $46 \%$ & Moore and cols. (2002) \\
\hline $\begin{array}{l}\text { cabergoline+ } \\
\text { Somatostatin Analogue }\end{array}$ & $21 \%(42 \%)$ & $21 \%$ & $40 \%$ & Cozzi and cols. (2004) \\
\hline Incidence & 3 / million & 3 / million & 4 / million & Donangelo and cols. (2003) \\
\hline Mortality rate ${ }^{5}$ (annual) & $0.86 \%$ & $0.86 \%$ & $1.72 \%$ & $\begin{array}{l}\text { Donangelo and cols. (2003); SIM/ } \\
\text { DATASUS }\end{array}$ \\
\hline $\begin{array}{l}\text { Proportion of anti-secretory } \\
\text { medication use }\end{array}$ & $50 \%$ & $40 \%$ & $60 \%$ & Melmed and cols. (1998) \\
\hline Proportion of Hospitalization & 0 & 0 & $1.55 \%$ & SIH; Demographic Data/DATASUS \\
\hline
\end{tabular}


Table 3. Total Costs per treatment and Average Annual Cost per patient by somatostatin analogue, Public Health Care System Perspective (SUS), Brazil, reais (RS, 2005).

\begin{tabular}{|c|c|c|c|c|}
\hline \multicolumn{5}{|c|}{ Somatostatin analogue: octreotide LAR } \\
\hline Management & $\begin{array}{l}\text { Total costs* per } \\
\text { treatment(s)** }\end{array}$ & $\begin{array}{l}\text { Total costs* of } \\
\text { monitoring }\end{array}$ & $\begin{array}{l}\text { Number of } \\
\text { patients }\end{array}$ & $\begin{array}{l}\text { Average annual } \\
\text { cost per patient }\end{array}$ \\
\hline octreotide LAR & $R \$ 8,652,143$ & $\mathrm{R} \$ 61,064$ & 157 & $\mathrm{R} \$ 27,749$ \\
\hline Subsequent dose increase of octreotide LAR & $R \$ 4,858,895$ & $R \$ 26,258$ & 68 & $R \$ 35,920$ \\
\hline Subsequent substitution for cabergoline & $R \$ 348,285$ & $R \$ 6,305$ & 19 & R\$ 9,331 \\
\hline $\begin{array}{l}\text { Subsequent association of octreotide LAR and } \\
\text { cabergoline }\end{array}$ & R\$ 437,770 & $R \$ 2,621$ & 7 & $R \$ 31,456$ \\
\hline Subsequent radiotherapy & R\$ 699,755 & R\$ 8,909 & 25 & $R \$ 14,173$ \\
\hline Total & R\$ $14,996,848$ & $R \$ 105,156$ & 276 & $R \$ 27,359$ \\
\hline \multicolumn{5}{|c|}{ Somatostatin analogue: lanreotide SR } \\
\hline Management & $\begin{array}{l}\text { Total costs }{ }^{*} \text { per } \\
\text { treatment(s)** }\end{array}$ & $\begin{array}{l}\text { Total costs* of } \\
\text { monitoring }\end{array}$ & $\begin{array}{l}\text { Number of } \\
\text { patients }\end{array}$ & $\begin{array}{l}\text { Average annual } \\
\text { cost per patient }\end{array}$ \\
\hline lanreotide SR & $R \$ 10,760,350$ & $\mathrm{R} \$ 51,423$ & 132 & $\mathrm{R} \$ 40,954$ \\
\hline Subsequent dose increase of lanreotide SR & R\$ 10,491,342 & $\mathrm{R} \$ 26,740$ & 69 & R\$ 76,218 \\
\hline Subsequent substitution for cabergoline & $\mathrm{R} \$ 904,342$ & $R \$ 9,221$ & 28 & $R \$ 16,314$ \\
\hline $\begin{array}{l}\text { Subsequent association of lanreotide SR and } \\
\text { cabergoline }\end{array}$ & R\$ $1,325,811$ & $R \$ 3,832$ & 10 & $R \$ 66,482$ \\
\hline Subsequent radiotherapy & R\$ 1,964,239 & $R \$ 13,028$ & 37 & $R \$ 26,720$ \\
\hline Total & $R \$ 25,446,085$ & R\$ 104,244 & 276 & $R \$ 46,287$ \\
\hline
\end{tabular}

*Total costs corresponding to model time horizon (two years); **Each line of Management, after the respective somatostatin analogue, includes the previous treatment(s), according to the Brazilian Guideline for Acromegaly, as described in Figure 1. Time in each treatment is explained in "Material and Methods".

Table 4. Incremental cost, Disease Impact and Incremental Cost-Effectiveness Ratios, Acromegaly Treatment with octreotide LAR versus lanreotide SR, Public Health Care System Perspective (SUS), Brazil.

\begin{tabular}{|c|c|}
\hline Incremental cost (Net Savings) & - R\$ $10,448,324^{*}$ \\
\hline Cases of elevated GH avoided & 12 \\
\hline Cases of elevated IGF-I avoided & 17 \\
\hline Deaths avoided & 0.1 \\
\hline Life years saved (LYS) & 0.2 \\
\hline $\begin{array}{l}\text { Incremental cost/Case of elevated GH } \\
\text { avoided }\end{array}$ & Cost-saving \\
\hline $\begin{array}{l}\text { Incremental cost/Case of elevated } \\
\text { IGF-I avoided }\end{array}$ & Cost-saving \\
\hline Incremental cost/Death avoided & Cost-saving \\
\hline Incremental cost/LYS & Cost-saving \\
\hline
\end{tabular}

de Preços) (22). Octreotide LAR (20 mg) price was R\$ 2,106.97 in 2005 (23), R\$ 2,456.40 in 2006 (23) and in 2007 after CAP had a reduction to R\$2,420.95. The same price variation was applied to lanreotide SR, since it was not in the Public Health Care System after 2006.

None of the variations altered the ICER, which remained cost-saving.

\section{DISCUSSION}

The cost-effectiveness analysis (CEA) of somatostatin analogues in the treatment of acromegaly in Brazil showed that octreotide LAR strategy is dominant when compared to lanreotide SR strategy.

A decision tree was used to model the development of the disease and its management. For each treatment 
Table 5. Sensitivity Analysis, Acromegaly Treatment with octreotide LAR versus lanreotide SR, Public Health Care System Perspective (SUS), Brazil.

\begin{tabular}{|c|c|c|c|c|c|c|c|}
\hline & \multicolumn{4}{|c|}{ Variable } & & \multicolumn{2}{|c|}{ ICER } \\
\hline & \multicolumn{2}{|l|}{ Minimum } & \multicolumn{3}{|l|}{ Maximum } & & \\
\hline Incidence & 3/million & & 4/million & & & Cost-saving & Cost-saving \\
\hline Mortality rate & $2 \times$ GPMR$^{*}$ & & $4 \times$ GPMR $^{*}$ & & & Cost-saving & Cost-saving \\
\hline \multicolumn{8}{|l|}{$\begin{array}{l}\text { Drug } \\
\text { Efficacy** }\end{array}$} \\
\hline octreotide LAR & & $54 \%$ & & $58 \%$ & & Cost-saving & Cost-saving \\
\hline lanreotide SR & & $48 \%$ & & $50 \%$ & & Cost-saving & Cost-saving \\
\hline cabergoline & & $28 \%$ & & $46 \%$ & & Cost-saving & Cost-saving \\
\hline $\begin{array}{l}\text { cabergoline+somatostatin } \\
\text { analogue }\end{array}$ & & $21 \%$ & & $40 \%$ & & Cost-saving & Cost-saving \\
\hline \multicolumn{8}{|l|}{ Dose } \\
\hline octreotide LAR & & 20 mg/28 days & & & 30 mg/28 days & Cost-saving & Cost-saving \\
\hline lanreotide SR & & 30 mg/14 days & & & $30 \mathrm{mg} / 7$ days & Cost-saving & Cost-saving \\
\hline cabergoline & & $1 \mathrm{mg} /$ week & & & $3.5 \mathrm{mg} /$ week & Cost-saving & Cost-saving \\
\hline \multicolumn{8}{|l|}{ CAP $^{* * *}$ (Drug price) } \\
\hline octreotide LAR & & $R \$ 2,420.95$ & & & & Cost-saving & \\
\hline \multirow[t]{2}{*}{ lanreotide SR } & & R\$ 1,787.89 & & & & Cost-saving & \\
\hline & & Rate & & & Cost & & \\
\hline Hospitalization & & $1.55 \%$ & & & R\$ 709.40 & Cost-saving & \\
\hline
\end{tabular}

* General Population Mortality Rate (40-49 years of age); ** GH control; *** Coeficiente de Adequação de Preços.

option, the respective branch represented the period of time on that, the number of patients and the costs incurred until response is accomplished or not. Probabilities of death also changed to $\mathrm{GH}$ elevated cases controlled or not. Surgery was not considered in case of non response to association of a somatostatin analogue and dopamine agonist and was not initially included in the model. The absence of initial transsphenoidal surgery does not affect the results of the analysis. The costs for surgery will be the same for both strategies before drug therapy is introduced. Surgery can influence somatostatin analogue efficacy in regards to biochemical control when the medical therapy is prescribed after surgery (second line therapy). Because of that, in the model, data regarding somatostatin analogues efficacy as secondary treatment also included patients who had undergone surgery (18). As we analyzed the incremental costs and outcomes between octreotide LAR and lanreotide SR, previous events to the decision node will be the same for both somatostatin analogue strategies.

The model was based on a local guideline, as recommended by SUS. Non-adherence in clinical practi- ce to the guideline would affect both the structure and results of the model. Efficiency of guideline implementation can be very heterogeneous (24) so no assumption was made in the model. Another issue was that the Brazilian Guideline for the treatment of Acromegaly differs from international guidelines, which recommend GH receptor antagonist after inadequate response to a somatostatin analogue $(1 ; 25)$. GH receptor antagonist is not considered as a treatment option in the Brazilian Guideline (12).

Although the 2-year time horizon considered in the model was short, it was sufficient to follow response or not to the somatostatin analogues. The analysis also intended to be as close as possible to changes in the Public Health Care System, so the hypothetical cohort diagnosed in 2005 was followed for the period that both somatostatin analogues were offered by SUS, with prices still available in SIA (Ambulatory Information System).

The concern about replicating the reality of Public Health Care System into the model is due to the fact that this analysis is a post inclusion health economic eva- 
luation. In the literature, it is rare to find economic evaluations as tools to monitor health technologies already incorporated and to guide their continuity (26). This cost-effectiveness analysis contributes to the study of the disease and economic impacts of acromegaly in Brazil as well as to the assessment of the reimbursement of a specific technology (somatostatin analogue) by SUS.

Acknowledgements: We thank Wellington Mendes for explanations on radiotherapy treatment. This analysis was sponsored by Novartis Biociências S.A, Brasil. No other potencial conflict of interest relevant to this article was reported.

\section{REFERENCES}

1. Cook DM, Ezzat S, Katznelson L, Kleinberg DL, Laws ER Jr, Nippoldt TB, et al. American Association of Clinical Endocrinologists Medical guidelines for clinical practice for the diagnosis and treatment of acromegaly, Endocrine Practic. 2004;10(3).

2. Alexander L, Appleton D, Hall R, Ross WM, Wilkinson R. Epidemiology of acromegaly in Newcastle region. Clin Endocrinol (Oxf). 1980;12:71-9.

3. Etxabe J, Gaztambide P, Latorre P, Vasquez JA. Acromegaly: an epidemiological study. J Endocrinol Invest, 1993;16:181-7.

4. Donangelo I, Une K, Gadelha M. Diagnóstico e treatmento de acromegalia no Brasil. Arq Bras Endocrinol Metab. 2003;47(4).

5. Bengtsson B-A, Edén S, Ernest I, Oden A, Sjogren B. Epidemiology and long-term survival in acromegaly. A study of 166 cases diagnosed between 1955-1984. Acta Med Scand. 1988; 223:327-35.

6. Sheaves R, Jenkins P, Blackburn P, Huneidi AH, Afshar F, Medbak $S$ et al. Outcome of trans-sphenoidal surgery for acromegaly using strict criteria for surgical cure. Clin Endocrinol (Oxf). 1996;45:407-13.

7. Fahlbusch R, Honegger J, Buchfelder M. Surgical management of acromegaly. Endocrinol Metab Clin North Am. 1992; 21:669-92.

8. Nomikos P, Buchfelder M, Fahlbusch R. The outcome of surgery in 668 patients with acromegaly using current criteria of biochemical 'cure'. Eur J Endocrinol. 2005;152: 379-87.

9. Giustina A, Barkan A, Casanueva FF, Cavagnini F, Frohman L, Ho K, et al. Criteria for cure of acromegaly:a consensus statement. J Clin Endocrinol Metab. 2000;85:526-9.

10. Growth Hormone Research Society, Pituitary Society. Biochemical assessment and long-term monitoring in patients with acromegaly: statement from a Joint Consensus Conference of The Growth Hormone Research Society and The Pituitary Society. J Clin Endocrinol Metab. 2004;89:3099-102.

11. Boeving A, Borba LA, Rodrigues AM, Orichowski EB, Paz Filho GJ, Santos CM, Boguszewski CL. Outcome of surgical treatment for acromegaly performed by a single neurosurgeon and cumulative meta-analysis. Arq Bras Endocrinol Metab. 2006;50(5)884-92.
12. Brasil, Ministério da Saúde, Secretaria de Assistência à Saúde. Protocolo Clínico e Diretrizes Terapêuticas para Acromegalia - octreotida, lanreotida, bromocriptina e cabergolina, Portaria no 471, de 24 de junho de 2002.

13. Moore D, Meads C, Roberts, L, Song, F. The effectiveness and cost-effectiveness of somatostatin analogues in the treatment of acromegaly, Department of Public Health, University of Birmingham. 2002.

14. King Jr. JT, Justice A, Aron DC. Management of incidental pituitary microadenomas: a cost-effectiveness analysis, J Clin Endocrinol Metab. 1997;82(11)3625-32.

15. Jaffe CA. Reevaluation of conventional pituitary irradiation in the therapy of acromegaly. Pituitary. 1999;2:55-62.

16. Jenkins PG, Elliott EL, Carson MN, Bates PR. Use of a national database to explore the effects of pituitary irraditation on serum growth hormone and IGF-1 in acromegaly. J endocrinol. 1999; 163 Suppl:OCA.

17. Chanson P. Emerging drugs for acromegaly Expert Opin. Emerging Drugs. 2008;13(2):273-93.

18. Freda PU, Katznelson L, Lely AT vd, Reyes, CM, Zhao S, Rabinowitz, D. Long-acting somatostatin analog therapy of acromegaly: a meta-analysis. J Clin Endocrinol Metab. 2005;90(8) 4465-73.

19. Cozzi R, Attanasio R, Lodrini S, Lasio G. Cabergoline addition to depot somatostatin analogues in resistant acromegalic patients: efficacy and lack of predictive value of prolactin status. Clin Endocrinol (Oxf). 2004;61(2):209-15.

20. Melmed S, Jackson I, Kleinberg D, Klibanski A. Current treatment guidelines for acromegaly. J Clin Endocrinol Metab. 1998;83:2646-52.

21. Datasus. Sistema de Informações de Mortalidade (SIM), Available at: <http://tabnet.datasus.gov.br/cgi/deftohtm.exe?sim/ cnv/obtuf.def>. [Accessed: 15 october 2007].

22. Brasil. Diário Oficial da União, Seção 3, Comunicado no 7, 11 de junho de 2007.

23. Datasus. Sistema de Informações Ambulatoriais (SIA). Available at: <http://tabnet.datasus.gov.br/cgi/deftohtm.exe?sia/cnv/ pauf.def>. [Accessed: 15 october 2007].

24. Hoomans T, Evers SMAA, Ament AJHA, Hubben MWA, van der Weijden T, Grimshaw JM, et al. The methodological quality of economic evaluations of guideline implementation into clinical practice: a systematic review of empiric studies. Value Health. 2007;10(4)305-16.

25. Melmed S. Acromegaly, N Engl J Med. 2006;355:2558-73.

26. Bloom B. Use of Formal Benefit/Cost Evaluations in Health System Decision Making, Am J Manag Care. 2004;10:329-35.

Endereço para correspondência:

Alessandra Calabró

Av. Prof.Vicente Rao, 90

04636-000 São Paulo SP

E-mail: alessandra.calabro@novartis.com 